\title{
AN EMPIRICAL STUDY ON INVENTORY PERFORMANCE OF LISTED STEEL COMPANIES IN CHINA DURING THE 13TH FIVE-YEAR PLAN
}

\author{
${ }^{1}$ Wenlong YAO, ${ }^{2}$ Wenbin DING, ${ }^{1}$ Radim LENORT \\ ${ }^{1}$ VŠB - Technical University of Ostrava, Faculty of Materials Science and Technology, Ostrava, \\ Czech Republic, EU, marcoe@163.com \\ ${ }^{2}$ Hubei University of Technology, Wuhan, China, wbding@hbut.edu.cn
}

https://doi.org/10.37904/metal.2021.4297

\begin{abstract}
The 13th Five-Year Plan for Economic and Social Development of People's Republic of China lasted from 2016 to 2020. During the period, Chinese steel enterprises have maintained the status of "high yield, high inventory, high cost". Since the "Supply-Side Reform" started in 2016, the supply and demand situation has been improved, with price and production quantity both increasing. This article provides the model built upon the panel data of Chinese 29 listed steel companies from 2016 to 2020 and studies the impacts of supply chain concentration and lead time towards inventory performance from the perspective of Chinese listed steel companies. The study reveals that the shorter the purchase lead time and sales lead time of the steel companies, the higher the inventory turnover, while purchase concentration of these companies has no significant influence on inventory turnover.
\end{abstract}

Keywords: Supply chain, steel, inventory performance, panel data model

\section{INTRODUCTION}

In 2020, China's yield of crude steel had broken through 1 billion tons for the first time, and reaching 1.053 billion tons, which was $5.2 \%$ higher than the production in 2019. In the past years, China's steel industry has suffered considerably from serious inventory problems as witnessing a high-level yield. In 2011, the average inventory proportion among Chinese steel companies nearly reached $30 \%$ while the industry started the "Supply-Side Reform" at the beginning of the 13th Five-Year Plan in 2016. Under this situation, it is significant to research the actual performance of the reform from the inventory performance of Chinese steel industry. The present studies on inventory performance mainly focus on the aspects of products or models. Based on strict hypotheses and deductions, their effectiveness and universality still require to be examined by more empirical studies. Studies on inventory performance at the whole level of enterprises, especially the ones based on objective data, are still relatively insufficient nowadays. By sorting out empirical articles themed on inventory management, people can perceive that the attention has been paid predominantly to the impacts of the enterprises' self-factors and external macroeconomic factors on inventory while the influential factors by upstream raw material suppliers and downstream customers in the supply chain are less considered. Therefore, from the perspective of supply chain, this article will research various data, including supply chain concentration, lead time, and inventory performance of 29 domestic listed steel companies from 2016 to 2020 , comprehensively consider the influential factors related to upstream raw material suppliers and downstream customers, and discuss the impacts of purchase lead time, purchase concentration, sales concentration and sales lead time upon inventory performance under the premise of controlling the self-factors of enterprises and external macroeconomic factors. 


\section{LITERATURE REVIEW}

By setting three dependent variables of inventory holding level, inventory holding days, and inventory turnover as main streams, this article reviews the existing literature and summarizes the core factors affecting them and the outcomes.

As for studies about influential factors for inventory holding level, Roumiantsev et al.[1] find that the higher the demand uncertainty, the longer the purchase lead time and the higher the gross profit margin, the higher the inventory holding level; the higher the inventory holding cost and the larger the sales scale, the lower the inventory holding level. Quanwu Zhao et al.[2] conduct empirical studies and conclude that the bigger the inventory proportion of China's manufacturing companies, the higher the gross profit margin, the larger the company scale and the longer the lead time, the higher the inventory holding level.

Chen et al.[3] observe the impacts towards inventory holding days by introducing four macroeconomics variables of interest rate, GDP growth rate, inflation rate and PMI index into the model. However, the result shows that the above elements have not posed an significant impact to the decrease of the average holding days of total inventory and WIP inventory of US listed manufacturing companies from 1981 to 2000. Based on this, Chen et al.[4] continuously research US listed companies in the retail and wholesale industry from 1981 to 2000 and reached an aligned conclusion. The latest study indicates that the long-term data of 9 out of 14 US manufacturing industries support the conclusion of the lower the inventory level is, the better the enterprise performance, though the inventory level of different industries at different phases has posed different impacts on the performance[5].

Balakrishnan et al.[6] explores the influence of inventory turnover by taking 36 US companies adopting JIT production mode from 1985 to 1989 as samples and find that the lower the customer concentration, the higher the ROA, and the higher the ROA, the lower the inventory turnover, especially for WIP inventory. Gaur et al.[7] has developed an empirical model with the financial data of 311 US listed companies in the wholesale industry from 1987 to 2000 , reflecting that the higher the gross profit margin, the lower the inventory turnover; the higher the fixed assets proportion and the higher the actual sales and forecast ratio, the higher the inventory turnover. They also correct the inventory turnover according to the gross profit margin, fixed assets proportion and sales forecast deviation to make it possible for inventory turnover to be applicable to performance analysis and decision-making. On the basis of above studies, Garu et al.[8] further investigate how the company scale and sales growth rate affect inventory turnover with data of 353 companies from 1985 to 2003, concluding that the larger the scale and the higher the sales growth rate, the higher the inventory turnover; when sales decrease, the decline speed of inventory turnover is considerably faster than the increase of inventory turnover when sales boosts Quanwu Zhao et al.[9] have launched an empirical study with the financial data of Chinese listed companies in the clothing manufacturing industry. They unveil that the higher the gross profit margin, the lower the inventory turnover, the larger the fixed assets proportion, the higher the inventory turnover, and the sales turnover rate is more sensitive to inventory turnover than sales growth when sales decline. Later, they have also systematically investigated the status quo of the inventory management of domestic retail enterprises. Studies reveal that there is no correlation between gross profit margin and inventory turnover but the impacts of fixed assets proportion towards inventory turnover remain the same as that of domestic clothing manufacturing industry and the impact of sales growth rate on inventory turnover is more obvious when sales decline[10]. Hong Cai et al.[11] choose Chinese listed companies in the clothing manufacturing industry as samples, figuring out that inventory turnover has a significant negative correlation with lead time, gross profit margin and inventory proportion, and features a significant positive correlation with company scale.

In summary, scholars' studies on factors influential to inventory focus mainly on the self-factors of enterprises and external macroeconomics factors while rarely extend the attention to the upstream and downstream of supply chain to consider the influence from upstream raw materials suppliers and downstream customers. Hereby, this article will stress studying if the concentration and lead time of the supply chain, especially for the ones of steel companies, can affect inventory turnover and the degree of impact. 


\section{HYPOTHESIS PRESENTATION}

This article refers to the measurement method of purchase lead time used by Roumaintsev et al.[2], with the turnover days of accounts payable as the measurement factor. The length of purchase lead time will affect a company's inventory level of raw materials. The extension of purchase lead time will increase the delivery time interval of raw materials and companies need a higher level of inventory to maintain the production demand when waiting for the supplement of raw materials. The calculation formula of classical safety inventory proves this effect as according to it, the purchase lead time of raw materials is positively related to safety inventory. Since the safety inventory is an important element of raw-material inventory, hereby the longer the purchase lead time, the higher the inventory level, and the lower the inventory turnover.

Hypothesis 1: Purchase lead time is significant negatively correlated with inventory turnover of steel companies.

Supply chain concentration refers to the concentration degree of core raw-material suppliers, customer numbers and transaction volume of manufacturing companies. Serving as a valuable reflection of supply chain partnership, it includes the purchase concentration in the upstream of the supply chain and the sales concentration in the downstream[12].

The higher the purchase concentration, the fewer suppliers and the higher transaction volume with core suppliers, and it represents a close partnership relationship. It can impact the inventory turnover of steel enterprises from two aspects: on the one hand, reducing the number of suppliers can enhance the information sharing among supply chain partners and leverage the agility of the supply chain, hereby can shorten the lead time, reduce inventory, and incline the inventory turnover[13]; on the other hand, it can help companies execute inventory strategies such as VMI, JIT, and CPFR. Through empirical studies, Quanwu Zhao et al. prove that the partnership relationship measured by purchase concentration has positive impact on inventory turnover [14].

The higher the sales concentration, the fewer the number of customers, the higher the sales volume with core customers, and the closer the partnership. It can pose an influence on the inventory turnover of steel companies from two aspects. On the one hand, the higher the sales concentration, the fewer the number of downstream customers. Cachon and Olivares[15] perceive that fewer customers can lead to a decreasing magnitude of demand change, a lower level of inventory, and a higher inventory turnover. On the other hand, the higher the sales concentration, the better the information sharing and communication efficiency between steel companies and downstream customers. It can reduce the influence of bullwhip effect, reduce uncertainty of demand, and boost the inventory turnover. Besides, by virtue of panel analysis, Quanwu Zhao et al.[16] figure out that the higher sales concentration of domestic manufacturing industry, the higher the inventory turnover.

Hypothesis 2: Purchase concentration is significant positively correlated with inventory turnover of steel companies.

Hypothesis 3: Sales concentration is significant positively correlated with inventory turnover of steel companies.

Drawing on the measurement method of purchase lead time, this article expresses the sales lead time with days sales outstanding. By increasing credit sales, companies expand market share, resulting in the rising of accounts receivable, decline of cash flow, and inclining of sales lead time. However, the inventory risk and the level of inventory can be reduced, with inventory turnover leveraged. Yongjun Li[17] analyzes the operation performance of listed steel companies with a method named principal component analysis. He finds that there is a certain negative correlation between inventory turnover and accounts receivable turnover. The shorter the sales lead time, the faster the company's payment collection, the more cash flow, and the more budget can be paid for inventory, the more stock that a company will prepare for maintaining customer demands. In this way, 
the degree of inventory rises, and the turnover goes down. Hereby, this study will first assume that the inventory turnover of steel companies is negatively correlated with sales lead time.

Hypothesis 4: Sales lead time is negatively correlated with the inventory turnover of steel companies.

\section{SAMPLE, VARIABLE AND MODEL SELECTION}

In this article, by determining the research samples and variables, collecting relevant cross-section data and time series data,and then the panel data models was established for analysis.

\subsection{Study Sample}

After screening, this article sets the study samples as 29 Chinese listed companies whose main business is steel manufacturing. The chosen samples are industrially representative which ensures that the study outcome is instructive to the inventory management of steel industry. Data used in this article is collected from Wind database, annual reports of these companies, and Chinese Statistical Yearbooks. By removing missing values and outliers, this article finally gains 145 samples to examine the hypotheses.

\subsection{Definition and Measurement of Variable}

To examine the hypotheses, this article investigates the relationship between inventory turnover and purchase lead time, purchase concentration, sales lead time, and sales lead time based on the financial index of listed companies. Simultaneously, it checks the four factors' impacts on inventory turnover under the premise of controlling the companies' characteristic variables (scale, gross profit, and type) and macro factors (annual growth rate of total investment in fixed assets for the whole society and GDP annual growth rate). The analysis of each index is displayed in Table 1.

Table 1 Definition of Variables

\begin{tabular}{|c|c|c|}
\hline Variable & Type & Definition \\
\hline IT & explained variable & inventory turnover \\
\hline PLT & explanatory variable & purchase lead time: turnover days of accounts \\
payable
\end{tabular}

\subsection{Panel Data Model}

Here, the first panel data model is established on the data of listed steel companies.and then the second panel ata model is established by adding macro factors. 
Model 1

$\log I T_{i t}=a_{1}+b_{1} \log P L T_{i t}+b_{2} \log P C_{i t}+b_{3} \log S C_{i t}+b_{4} \log S L T_{i t}+b_{5} \log S_{i t}+b_{6} \log G M_{i t}+b_{7} P T+v_{i}+\varepsilon_{i t}$

$i$ stands for a certain company, $t$ stands for the year, $v_{i}+\varepsilon_{i t}$ is the disturbance, $v_{i}$ is the individual characteristics that are unobservable and unchanged over time, and $\varepsilon_{i t}$ is the disturbance changes according to individuals and time.

Equation(1) mainly studies the impacts of purchase lead time, purchase concentration, sales concentration, and sales lead time towards inventory turnover, under the premise of controlling company characteristics.

Model 2:

$\log I T_{i t}=a_{2}+b_{1} \log P L T_{i t}+b_{2} \log P C_{i t}+b_{3} \log S C_{i t}+b_{4} \log S L T_{i t}+b_{5} \log S_{i t}+b_{6} \log G M_{i t}+b_{7} P T+$

$b_{8} T F A I G R_{1}+b_{9} G G D P_{t}+v_{i}+\varepsilon_{i t}$

Based on equation(1), equation(2) introduces two control variables of macro factors which are the rate of total investment in fixed assets for the whole society and GDP annual growth rate. On the one hand, it intends to investigate the impact of macro factors on inventory turnover of steel companies; on the other hand, it aims to observe how the four factors mentioned can influence inventory turnover after macro factors are eliminated.

\section{EMPIRICAL RESULTS AND ANALYSIS}

First of all, the study operates descriptive statistics and a multiple collinearity test on the explanatory variables involved in Model 1 and Model 2.

Table 2 Descriptive Statistical Analysis

\begin{tabular}{|c|c|c|c|c|c|}
\hline Variable & Observations & Mean & Std.Dev. & Min & Max \\
\hline IT & 145 & 1.867 & 0.773 & 0.269 & 8.028 \\
\hline PLT & 145 & 3.926 & 0.627 & 2.663 & 6.366 \\
\hline PC & 145 & 3.652 & 0.591 & 2.02 & 8.037 \\
\hline SC & 145 & 3.121 & 0.586 & 1.621 & 4.568 \\
\hline SLT & 145 & 1.813 & 1.535 & -3.262 & 4.942 \\
\hline S & 145 & 5.57 & 1.207 & 1.909 & 8.022 \\
\hline GM & 145 & 2.582 & 0.948 & -1.552 & 11.78 \\
\hline TFAIGR & 145 & 0.991 & 0.0787 & 0.868 & 1.081 \\
\hline GGDP & 145 & 105.8 & 1.773 & 102.3 & 107.0 \\
\hline
\end{tabular}

From Table 2, it can be found that the extreme value gaps of inventory turnover (IT), purchase lead time (PLT), and purchase concentration $(\mathrm{PC})$ are high while their standard deviations are not large, meaning that the overall difference of inventory turnover (IT), purchase lead time (PLT), and purchase concentration (PC) correspondingly are not large. Sales lead time (SLT), scale (S), and gross profit margin (GM) are not only having relatively obvious differences in extreme value gaps, but also all feature a standard deviation more than 1, which means that the data difference among sales lead time (SLT), scale (S), and gross profit margin (GM) is considerable. Therefore, it indicates that the sales lead time and operation scale of different steel companies vary profoundly. 
Table 3 Multiple Collinearity Test Results

\begin{tabular}{|l|c|c|c|c|c|c|c|c|}
\hline & $\log \mathbf{S}$ & $\log$ SLT & $\log$ SC & log PLT & log PC & log GM & GGDP & TFAIGR \\
\hline VIF of Model 1 & 1.92 & 1.78 & 1.42 & 1.32 & 1.19 & 1.07 & & \\
\hline VIF of Model 2 & 1.96 & 1.78 & 1.42 & 1.34 & 1.19 & 1.09 & 1.33 & 1.4 \\
\hline
\end{tabular}

By launching VIF test on the above variables, it can be told that the VIF values of all variables are less than 5 , reflecting that there is no serious multiple collinearity problem and the regression analysis at the next step can be carried out.

Table 4 Test of Model Selection

\begin{tabular}{|c|c|c|c|}
\hline Model Selection & Test Method & Model 1 (P Value) & Model 2 (P Value) \\
\hline OLS \& FE & F test & Prob $>F=0.0052$ & Prob $>F=0.004$ \\
\hline FE \&RE & Hausman test & Prob $>$ chi2 $=0.9175$ & Prob $>$ chi2 $=0.8187$ \\
\hline
\end{tabular}

From Table 4, when Model 1 and Model 2 passed $F$ test respectively, $P$ value rejected OLS model at $1 \%$ significant level. Then the two models were tested by Hausman test correspondingly, with the outcome indicating that we cannot reject the hypothesis that the disturbance term $v_{i}$ is not related to the explanatory variable. Hereby, the random effect model shall be adopted.

\begin{tabular}{r|rrrrrr}
\hline logit & Coef. & Std. Err. & $z$ & P > z| & [95\% Conf. Interval] \\
\hline logplt & -.3181036 & .1249479 & -2.55 & 0.011 & -.5629969 & -.0732102 \\
logpc & -.0303729 & .1069291 & -0.28 & 0.776 & -.2399501 & .1792044 \\
logsc & .2120592 & .1269408 & 1.67 & 0.095 & -.0367403 & .4608586 \\
logslt & -.1329982 & .0578177 & -2.30 & 0.021 & -.2463188 & -.0196777 \\
logs & .204249 & .0796177 & 2.57 & 0.010 & .0482013 & .3602967 \\
loggm & -.0277795 & .0598876 & -0.46 & 0.643 & -.1451571 & .0895982 \\
pt & .3176636 & .2052376 & 1.55 & 0.122 & -.0845947 & .719922 \\
- cons & 1.614621 & .919902 & 1.76 & 0.079 & -.1883536 & 3.417596 \\
\hline sigma_u & .28271252 & & & & & \\
sigma_e & .61425817 & & & & &
\end{tabular}

Figure 1 Panel Analysis Results of Model 1

\begin{tabular}{r|rrrrrr}
\hline logit & Coef. & Std. Err. & $z$ & P $>|z|$ & [95\% Conf. Interval] \\
\hline logplt & -.3081978 & .1270343 & -2.43 & 0.015 & -.5571805 & -.059215 \\
logpc & -.0341418 & .1067712 & -0.32 & 0.749 & -.2434095 & .175126 \\
logsc & .216667 & .1270708 & 1.71 & 0.088 & -.0323871 & .4657211 \\
logslt & -.1309114 & .0582425 & -2.25 & 0.025 & -.2450646 & -.0167583 \\
logs & .200881 & .0818916 & 2.45 & 0.014 & .0403765 & .3613855 \\
loggm & -.0420561 & .0603255 & -0.70 & 0.486 & -.1602919 & .0761797 \\
pt & .313511 & .2088521 & 1.50 & 0.133 & -.0958315 & .7228536 \\
tfaigr & -1.025927 & .7825234 & -1.31 & 0.190 & -2.559645 & .5077903 \\
ggdp & .053866 & .0331019 & 1.63 & 0.104 & -.0110126 & .1187445 \\
cons & -3.052192 & 3.362736 & -0.91 & 0.364 & -9.643034 & 3.53865 \\
sigma_u & .28782795 & & & & & \\
sigma_e & .60911742 & & & &
\end{tabular}

Figure 2 Panel Analysis Results of Model 2 
According to Figure 1 and Figure 2, the following results are reached:

Purchase lead time has incurred a significant negative impact upon enterprise inventory turnover, which is consistent with the classic inventory model and supports the hypothesis 1 . As steel companies are faced with challenges such as the raw-material purchase is distant, high cost, large volume and risky, and out of stock is intolerant in production, they need set a lead time to prevent the uncertainty of suppliers' arrival and ensure the continuous production. In practical operation, since steel companies can not be sure about the accuracy of the delivery time, they usually reserve a certain buffer for the delivery date, causing a long lead time. However, the prolonging of lead time cannot only increase the volume of safety inventory, but also worsen the demand fluctuation caused by bullwhip effect, which then results in an increasing order quality of raw materials, a high level of inventory of raw materials, and a decreasing inventory turnover.

The steel industry is a resource intensive industry, which means that the stability of acquiring raw materials plays a vital role in production performance. The hypothesis 2 has not been supported, reflecting that purchase concentration poses no significant positive impact on inventory turnover of steel companies. It might because that more than $70 \%$ of China's steel companies' demand upon upstream raw materials is solved by importing, external factors such as the Sino-US trade war worsening the instability of raw-material supply during the period of 13th Five-Year Plan, and the rapid development of Chinese economy enlarging the demand of steel, steel companies have witnessed a rising trend in both inventory turnover and demand for raw materials. Hereby, to ensure the agility and elasticity of supply chain, companies have extended the supplier base, leading to the decreasing proportion of top 5 suppliers.

Sales concentration can generate significant positive impact on the inventory turnover of steel companies, with hypothesis 3 supported. By leveraging sales concentration, integrating the downstream of supply chain, building a close partnership with core customers, companies can realize the sharing of inventory information, production planning information, and demand forecast information, eliminate uncertainty of demand, decrease inventory level, and incline inventory turnover.

Sales lead time can incur significant negative impact on the inventory turnover of steel companies, with hypothesis 4 supported. Credit sale is a common scenario among both domestic and foreign steel listed companies. Since most of the listed steel companies in Chine are operated by the central government, they always have various financing channels. In the past years, when domestic steel companies could not collect payment from customers in time, they could leverage the company to maintain normal operation, which resulted in their little attention to payment collection. However, since the deleveraging of steel industry after the launch of "Supply-Side Reform" in the steel industry in 2016, companies must value the speed of payment collection to reduce the debt ratio. Hence, from the analysis results, during the 13th Five-Year Plan period, China's steel companies have fulfilled stable and efficient improvements in the task of reducing leverages.

\section{SUGGESTIONS}

Based on the study outcomes, suggestions for the steel companies are:

- $\quad$ Shorten the purchase lead time, strengthen delivery coordination with suppliers, and minimize the inventory level in the case of ensuring daily production. According to the study described in this article, it has been proven that the purchase lead time has a negative impact on inventory turnover. As a longer lead time will result in a lower inventory turnover, a high inventory level will influence the enterprise's inventory performance.

- Increase the concentrations (purchase concentration and sales concentration) of supply chain, integrate and optimize the supply chain, focus on improving the inventory turnover by establishing long-term and stable partnerships with core suppliers or customers, and enhance the controlling towards purchase and sales channels. 
- $\quad$ Pay special attention to the integration and cooperation with core upstream raw-material suppliers, as well as supplier management. As supply chain management regards customers as the development orientation, enterprises tend to value customer management while neglecting supplier management. The outcome of this article reveals that the hypotheses on purchase concentration in the two explanatory variables related to the supplier level have not been supported, which indicates that on the supply chain of Chinese steel companies, the upstream ironstone suppliers occupy monopoly positions and steel companies are disadvantaged in negotiations. Moreover, as the price of ironstone keeps rising, Chinese steel companies shall never ignore the integration and cooperation with suppliers when attaching importance to supply chain elasticity.

- As steel industry is a pillar industry of the nation, steel companies are suggested to closely keep track of the development of the global economic situation and national economic policies, adjust production plan according to the actual market demand, and continuously strengthen the "Supply-Side Reform". Besides, companies shall avoid expanding the investment on fixed assets and production capacity blindly or else it may result in the overstocking of inventory and a drop in profit.

\section{CONCLUSION}

Through the study, it can be concluded that during China's 13th Five-Year Plan, the purchase lead time and sales lead time of steel companies have incurred significant negative impact upon inventory turnover. Sales concentration is positively influential to inventory period apparently while purchase concentration has no significant impact on that. As inventory is a common challenge faced with steel companies, the competition between companies has evolved into competition between supply chains. To consider inventory problems from the perspective of supply chain is of cardinal importance for steel companies at this moment. Though according to the analysis outcome of this study, the inventory performance during the period of 13th Five-Year Plan has been effectively improved when compared to the situation at the beginning of the 21 st Century, companies shall still comprehensively take the impacts of related upstream and downstream factors upon inventory into consideration, decrease inventory level, and boost the inventory turnover.

\section{REFERENCES}

[1] ROUMIANTSEV, S., NETESSINE, S. What can be learned from classical Inventory models: A cross - industry empirical investigation. Manufacturing \& Service Operations Management. 2007, vol. 9, pp. 409-429.

[2] ZHAO, Q.W., LIAO, Y.H., HUANG, Y.F. An empirical study on inventory performance of manufacturing sector in China: Based on Public-listed companies data from 1997 to 2010. Journal of Applied Statistics and Management. 2012, vol. 31, pp. 207-216.

[3] CHEN, H., FRANK, M.Z., WU, O.Q. What actually happened to the inventories of american companies between 1981 and 2000. Management Science. 2005, vol. 51, pp. 1015-1031.

[4] CHEN, H. FRANK, M.Z., WU, O.Q. U.S. Retail and wholesale inventory performance from 1981 to 2004. Manufacturing \& Service Operations Management. 2007, vol. 9, pp. 430-456.

[5] SHIN, H., WOOD, C.C., JUN, M. Does effective inventory management improve profitability empirical evidence from U.S. manufacturing industries. International Journal of Information Systems and Supply Chain Management. 2016, vol. 9, pp. 26-45.

[6] BALAKRISHNAN, R., LINSMEIER, T.J., VENKATACHALAM, M. Financial benefits from JIT adoption: effects of customer concentration and cost structure. The Accounting Review. 1996, vol. 71, pp. 183-205.

[7] GAUR, V., FISHER, M.L., RAMAN, A. An econometric analysis of inventory turnover performance in retail services. Management Science. 2005, vol. 51, pp. 181-194.

[8] GAUR, V., KESAVAN, S. The effects of firm size and sales growth rate on inventory turnover performance in the U.S. retail sector. Supply Chain Management. 2008, pp. 25-52. 
[9] ZHAO, Q.W., HUANG, Y.F., ZHU, D.L. An empirical study of inventory productivity of apparel \& foot wear industry in China_Based on public-listed companies data from 1996 to 2008 in Shanghai and Shenzhen. East China Economic Management. 2009, vol. 23, pp. 131-137.

[10] ZHAO, Q.W., HUANG, Y.F., BU, X.Z. An empirical study of inventory turnover performance of retail sector in China: Based on public-listed companies data. Journal of Industrial Engineering and Engineering Management. 2010, vol. 2, pp. 48-55.

[11] CAI, H., GAM, X.Y., ZHOU, J.R. Research on textile and garment supply chain inventory control and enterprise performance management. China Management Informationization. 2010, vol. 3, pp. 84-87.

[12] DANNY L J., WILLIAM F. W, ZACH G. Z. Concentrated Supply Chain Membership and Financial Performance: Chain-and Firm-level Perspectives. Journal of Operations Management. 2010, vol. 28, pp. 1-16.

[13] CHEN, I.J., ANTONY, P., AUGUSTINE, A.L. Strategic Purchasing, Supply Management, and Firm Performance. Journal of Operations Management. 2004, vol. 22, pp. 505-523.

[14] ZHAO, Q.W., WANG, Q., HUANG, Y.F. An empirical study on relationship between supply chain partnership of medication industry in China and enterprise performance. Logistics Technology. 2009, vol. 28, pp. 173-220.

[15] CACHON, G.P., OLIVARES, M. Drivers of Finished - Goods Inventory in the U.S. Automobile Industry. Management Science. 2010, vol. 56, pp. 202-216.

[16] ZHAO, Q.W., WANG, Q., HUANG, Y.F. An empirical study on relationship of supply chain partnership and enterprise performance from manufacturing industry in China. East China Economic Management. 2010, vol. 24, pp. 128-131.

[17] LI, Y.J. Analysis of operation of listed steel companies at home and abroad. China Steel Focus. 2012, vol. 7, pp. 33-37. 